\title{
Adherence of Streptococcus pneumoniae to Polystyrene Plates and Epithelial Cells and the Antiadhesive Potential of Albumin and Xylitol
}

\author{
VICENTE RUIZ, VIOLETA RODRÍGUEZ-CERRATO, LORENA HUELVES, GEMA DEL PRADO, PLÍNIO NAVES, \\ CARMEN PONTE, AND FRANCISCO SORIANO
}

Department of Medical Microbiology and Antimicrobial Chemotherapy, Fundación Jiménez Díaz-Capio, 28040 Madrid, Spain

\begin{abstract}
Aimed to prevent Streptococcus pneumoniae biofilm infections, we studied the adherence of nine pneumococcal strains to polystyrene plates and on epithelial cells and the antiadhesive effect of albumin and xylitol. The adherence was variable among strains, but there was a good correlation between their adherent ability and binding to abiotic material and cells. Strains of serotypes $6 \mathrm{~B}$ and $23 \mathrm{~F}$ were the most adherent organisms, whereas serotype 3 strains were the least adherent. Human serum albumin (HSA) enhanced bacterial growth at low concentrations $(0.5-2.5 \%)$ but inhibited it at $10 \%$. Xylitol inhibited bacterial growth of all strains at concentrations ranging from 5 to $15 \%$. Exposure to $0.5-5 \%$ HSA in solubilized form and to $5 \%$ HSA precoating of plates diminished adherence to polystyrene $>80 \%$ for all strains, except for serotype 3 strains. Contrarily, 0.5 and $5 \%$ xylitol did not diminish significantly pneumococcal adherence to polystyrene plates or on epithelial cells. Our results suggest that 1) the potential application of HSA coatings on medical devices to inhibit pneumococcal adherence and 2) the possible beneficial effect of xylitol in preventing some pneumococcal infections could be because of its antimicrobial activity rather than to an antiadhesive effect. (Pediatr Res 69: 23-27, 2011)
\end{abstract}

Ctreptococcus pneumoniae is a common colonizer of the $\checkmark$ human upper respiratory tract and a leading cause of acute otitis media, community-acquired pneumonia, bacteremia, and bacterial meningitis. Bacterial adherence allows the organism to bind to eukaryotic cells and inert material; thus, it may be considered the first step for pathogenicity. Bacterial adhesion to inert material is probably mediated by physicochemical interaction, wherein many factors are involved, including cell envelope plasticity of bacteria, the target substratum properties, and environmental features (1). Once bacterial cells adhere to any surface, accretion of bacteria can ensue with bacterial cluster formation and further biofilm development (2).

Received January 5, 2010; accepted August 20, 2010.

Correspondence: Violeta Rodríguez-Cerrato, M.D., Ph.D., Department of Molecular Microbiology and Infection Biology, Centro de Investigaciones Biológicas (CSIC), Ramiro de Maeztu 9, 28040 Madrid, Spain; e-mail: vrodriguez@cib.csic.es

Supported, in part, by Fondo de Investigaciones Sanitarias (PI060048), Comunidad Autónoma de Madrid (COMBACT-CM S-BIO-0260/2006 [V.R.-C.] and CPI/0305/2007 [G.P.]), Fundación Conchita Rábago [L.H.], and the European Union Al $\beta$ an program [P.N.]. V.R.-C. is currently supported by the Subprogram Juan de La Cierva (JCI-200802690), Ministerio de Ciencia e Innovación, Spain.
Pneumococcal adherence to clinically used abiotic material has not been deeply investigated $(3,4)$, but pneumococcal binding to certain devices (i.e. tympanostomy tubes and cochlear implants) may lead to difficult-to-treat complications $(5,6)$. To decrease bacterial adherence to abiotic surfaces, several compounds, including plasma, serum, albumin, bacterial proteins, heparin, gelatin, pepsin, and saliva, have been tested (1). Because bacterial adhesion to inert material is diminished in the presence of serum and albumin, their use as coatings for foreign medical devices has been advocated (7,8). However, few studies have searched compounds with antiadhesive properties against pneumococci (4). Some reports have suggested that xylitol can prevent pneumococcal acute otitis media $(9,10)$, although the mechanisms underlying such beneficial effect have not been completely elucidated (11-14), but a potential interference with bacterial adherence was proposed (12).

The aims of this study were, first, to determine the binding properties of different pneumococcal strains to polystyrene plates and on epithelial cells under different experimental conditions, and second, to evaluate the effect of albumin and xylitol on the adherence phenomenon.

\section{MATERIALS AND METHODS}

Bacterial strains. All the strains used in this study are listed in Table 1. These strains were selected in basis of the serotypes that are commonly involved in human infections. Hereinafter, the strains are described by the numbers followed by their serotype.

Compounds and effects on bacterial strains. Human serum albumin (HSA) and xylitol were purchased from Sigma Chemical Co.-Aldrich (St. Louis, MO). Minimum inhibitory concentrations (MICs) of HSA and xylitol were determined for the nine strains by broth microdilution methodology (15) using cation-adjusted Mueller Hinton broth (CA-MHB; Becton Dickinson, $\mathrm{CO}$, Sparks, MD) enriched with $5 \%$ lysed horse blood.

Adherence to polystyrene (microtiter) plates and effects of solubilized albumin and xylitol. Isolated colonies from blood agar plates incubated for $20 \mathrm{~h}$ at $35^{\circ} \mathrm{C}$ in a $5 \% \mathrm{CO}_{2}$ atmosphere were used to prepare inocula. A bacterial suspension was prepared in prewarmed CA-MHB adjusted to an OD equivalent to $10^{8}$ colony-forming units $(\mathrm{CFU}) / \mathrm{mL}$, diluted $1 / 2$ in CA-MHB, and then $200 \mu \mathrm{L}$ per well were transferred to flat-bottom polystyrene, nontissue culture-treated 96-well microtiter plates (Greiner Bio-one, Frickenhausen, Germany). After 1 -h incubation at $35^{\circ} \mathrm{C}$ in air, the liquid was removed

\footnotetext{
Abbreviations: CA-MHB, cation-adjusted Mueller Hinton broth; CFU, colony-forming units; HSA, human serum albumin; MIC, minimum inhibitory concentration
} 
from the wells, and the wells were gently washed 10 times with saline. After the last washing, $50 \mu \mathrm{L}$ of CA-MHB was added to each well and sonicated at $35 \mathrm{kHz}$ (Bandelin Sonorex TK2; Schaltec GMBH, Morffelden-Waldorf, Germany) for $2 \mathrm{~min}$. Material removed was resuspended in $150 \mu \mathrm{L}$ of CA-MHB, diluted, and plated on blood agar plates for colony counting.

The effect of HSA and xylitol both at 0.5 and $5 \%(\mathrm{wt} / \mathrm{vol})$ on the adherence to polystyrene plates was also studied following the previously described method. The adherence rate for each strain unexposed (control) and exposed to the compounds was arbitrarily expressed as CFU recovered per $10^{6} \mathrm{CFU}$ of initial inoculum, because no bacterial growth was detected during the incubation period. All experiments were done five times by duplicate, and means (SD) were calculated.

Adherence to albumin pretreated polystyrene plates. Wells of two polystyrene plates were pretreated by adding $200 \mu \mathrm{L}$ of 5\% HSA, and then, one plate was incubated at $35^{\circ} \mathrm{C}$ for $2 \mathrm{~h}$ and the second plate at $30^{\circ} \mathrm{C}$ for $24 \mathrm{~h}$. Control wells containing only CA-MHB were also included. Later, both plates were washed aseptically with the same quantity of CA-MHB and dried at $37^{\circ} \mathrm{C}$ for $20 \mathrm{~min}$. The adherence of all pneumococcal strains was studied following the same methodology as above. All experiments were done five times by duplicate, and means (SD) were calculated.

Adherence to epithelial cells and effect of xylitol. The adherence to epithelial cells was studied using a human lung alveolar carcinoma epithelial cell line A549 (ATCC CCL-185) and prepared as previously described (16). Briefly, cells were grown in DMEM (GIBCO, NY) with $10 \%$ FCS, penicillin $\mathrm{G}(100 \mathrm{U} / \mathrm{mL})$, and streptomycin $(100 \mu \mathrm{g} / \mathrm{mL})$ and maintained in DMEM with $2 \%$ FCS. Washed A459 monolayers preformed in 24-well tissue culture trays (Greiner Bio-one) were exposed to $500 \mu \mathrm{L}$ of midlogarithmic phase cultures of each pneumococcal strain with $\sim 10^{6} \mathrm{CFU} / \mathrm{mL}$ and diluted in DMEM plus $10 \%$ FCS in presence or absence of xylitol at 0.5 and $5 \%$. After incubation for $2 \mathrm{~h}$ at $37^{\circ} \mathrm{C}$ in $5 \% \mathrm{CO}_{2}$ atmosphere, the culture fluid from each well was removed, diluted, and plated on blood agar plates for counting of final bacterial concentrations. Then, the monolayers were washed four times with PBS pH 7.5 and then detached from plate by treatment with $100 \mu \mathrm{L}$ of $0.25 \%$ trypsin and $0.02 \%$ EDTA (Sigma Chemical Co.). Epithelial cells were next lysed by addition of $400 \mu \mathrm{L}$ of $0.025 \%$ Triton X-100 (Sigma Chemical Co.), and $100-\mu \mathrm{L}$ aliquots (and serial 10-fold dilutions thereof) were plated on blood agar to determine the total number of adherent bacteria. The adherence rate for each strain was arbitrarily expressed as CFU recovered per $10^{6} \mathrm{CFU}$

Table 1. Pneumococcal strains, serotypes, sources, and in vitro susceptibility to HSA and xylitol

\begin{tabular}{|c|c|c|c|c|}
\hline \multicolumn{3}{|c|}{ No. strain } & \multicolumn{2}{|c|}{$\operatorname{MIC}(\%, \mathrm{wt} / \mathrm{vol})$} \\
\hline Reference & Serotype & Source & HSA & Xylitol \\
\hline 1-AR33118 & 3 & Respiratory tract & 10 & 5 \\
\hline 2-FL2812 & 3 & Blood & 10 & 10 \\
\hline 3-FL5629 & 3 & Blood & 10 & 10 \\
\hline 4-MJD1225 & $6 \mathrm{~B}$ & Blood & 10 & 15 \\
\hline 5-AR06016 & $9 \mathrm{~V}$ & Respiratory tract & 10 & 15 \\
\hline 6-AТCC49619 & $19 \mathrm{~F}$ & Sputum & 10 & 15 \\
\hline 7-FJD60 & $23 \mathrm{~F}$ & Blood & 10 & 15 \\
\hline 8-AR30118 & $23 \mathrm{~F}$ & Respiratory tract & 10 & 15 \\
\hline 9-MJD573 & $23 \mathrm{~F}$ & Cerebrospinal fluid & 10 & 15 \\
\hline
\end{tabular}

of final bacterial concentration. Assays were performed in duplicate, and results presented are the means (SD) of 10 wells.

Statistical analysis. The significance of differences between means was analyzed by the one-way ANOVA test. Levene's test was used to assess the equality of variances, and Welch's test was used because the variances differed statistically significant from each other. Comparisons between two groups (control versus any treated group or among two treated groups) were performed by Bonferroni's post test. All tests were two tailed. Differences with $p$ values $<0.05$ were considered significant. SPSS version 14.0 statistical package was used (SPSS Inc., Chicago, IL). When organisms showed no adherence, a value at the detection limit (1 CFU) was used for the calculation of mean values, and this value is the minimum value represented in the figures.

\section{RESULTS}

Effect of albumin and xylitol on pneumococcal growth. Table 1 presents the serotypes, sources, and susceptibility of nine pneumococcal strains to HSA and xylitol after 22-h exposure. Bacterial growth was inhibited for all strains by $10 \%$ HSA concentration (MIC), but it was stimulated by concentrations of $0.5-2.5 \%$. For all strains, growth was inhibited by $15 \%$ xylitol, showing the serotype 3 strains the lower MIC values (5-10\%), and particularly, bacterial growth was inhibited at $0.5 \%$ xylitol for strain number 3 (serotype 3 ).

Adherence of pneumococcal strains to polystyrene and effects of solubilized albumin and xylitol. Because no bacterial growth was detected during the incubation period (1 h), values were expressed in number of adhered CFU per $10^{6}$ CFU of initial inoculum (Fig. 1). The less adherent strains belonged to serotype 3 , whereas the most adherent belonged to serotypes $6 \mathrm{~B}$ and $23 \mathrm{~F}$. After exposure to any HSA concentration, the adherence diminished significantly $(>90 \%)$ for all strains $(p<0.0001)$, except for all serotype 3 strains. The adherence changes of all serotype 3 isolates were difficult to evaluate because of the poor adherence of their controls, which was close to the detection limit. The decreased effect on adherence after HSA exposure seems to be concentration dependent for five of the six valuable strains. Xylitol at 0.5 and $5 \%$ diminished the adherence in two and four strains, respectively, but again the differences were not significant.

Adherence of pneumococcal strains to polystyrene with and without 5\% albumin coating (pretreatment) for 2 or $24 \boldsymbol{h}$. As in the experiments with solubilized HSA, no bacterial growth was detected in any wells after the 1-h incubation period; thus, values were also expressed in number of adhered CFU per $10^{6} \mathrm{CFU}$ of initial inoculum (Fig. 2). The adherence diminished significantly $(p<0.0001)$ in $>80 \%$ for all strains
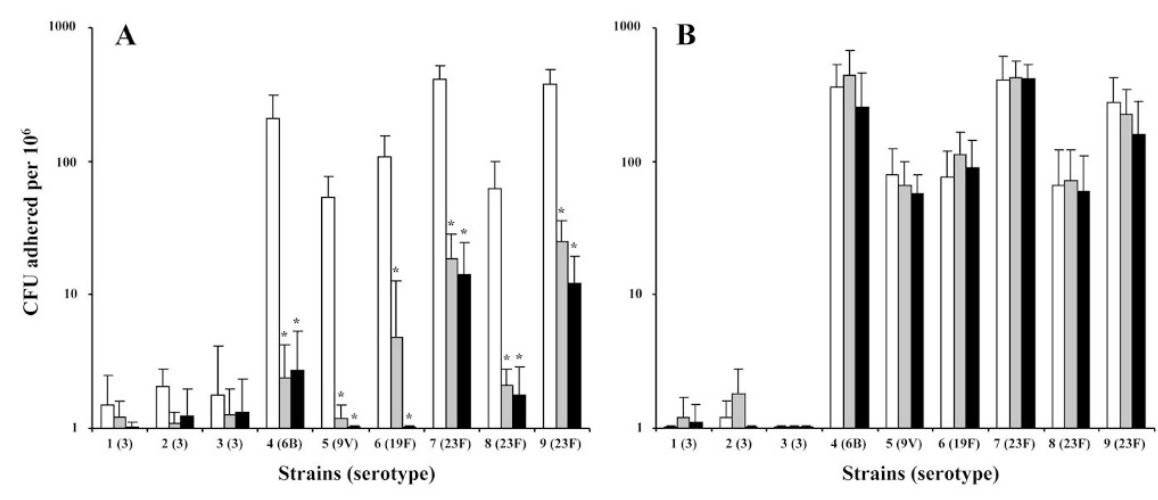

Figure 1. Adherence of pneumococcal strains to polystyrene alone (control; $\square$ ) and the effect of solubilized HSA $(A)$ and xylitol $(B)$ both at $0.5 \%$ (网) and 5\% (ם) (wt/vol). Figure represents means with $\mathrm{SD}$ (positive value) of CFU adhered per $10^{6} \mathrm{CFU}$ of inoculum $(n=10)$ : $* p<$ $0.0001,0.5$, or $5 \%$ vs control; one-way ANOVA with Bonferroni's multiple comparison test. 


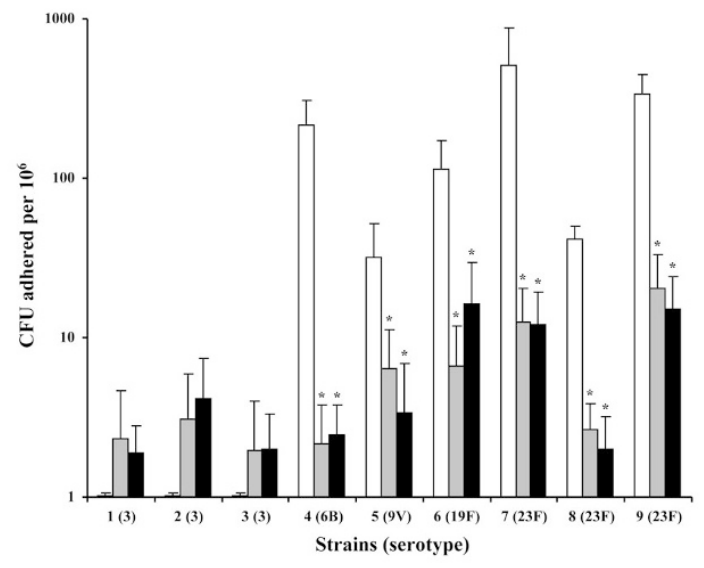

Figure 2. Adherence of pneumococcal strains to polystyrene without (control; $\square$ ) and with pretreatment of plates with $5 \% \mathrm{HSA}$ (wt/vol) for $2 \mathrm{~h}$ at $35^{\circ} \mathrm{C}$ (枸) and for $24 \mathrm{~h}$ at $30^{\circ} \mathrm{C}(\mathbf{\square})$. Figure represents means with SD (positive value) of CFU adhered per $10^{6} \mathrm{CFU}$ of inoculum $(n=10): * p<0.0001,5 \%$ HSA for $2 \mathrm{~h}$ or for $24 \mathrm{~h} v s$ control; one-way ANOVA with Bonferroni's multiple comparison test.

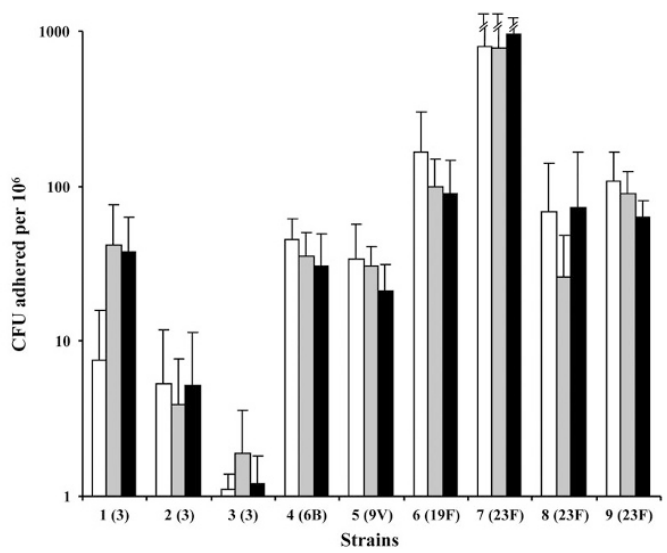

Figure 3. Adherence of pneumococcal strains to epithelial cell A549 monolayers alone (control; $\square$ ) and the effect of $0.5 \%$ (网) and $5 \%$ (口) (wt/vol) xylitol exposure. Adherence is given as means with SD (positive value) of $\mathrm{CFU}$ recovered per $10^{6} \mathrm{CFU}$ of final bacterial count $(n=10)$. No significant differences were found between control and xylitol groups $(p>0.05)$.

at 2 and $24 \mathrm{~h}$, except those of serotype 3. Again, no significant differences on adherence were observed for serotype 3 strains. The effect on bacterial adherence of 5\% HSA both in solubilized form (Fig. 1) and as pretreatment of wells (Fig. 2) was similar.

Effect of xylitol on pneumococcal adherence to epithelial cells. Contrarily to the previous experimental conditions, bacterial growth was detected during the 2-h incubation period. Xylitol at 0.5 and $5 \%$ slowed bacterial growth in one and six of the nine strains tested, respectively (Fig. $3)$. Therefore, the adherence values were expressed in number of adhered CFU per $10^{6} \mathrm{CFU}$ of final bacterial concentrations in the same well.

There was a good correlation between adherence to epithelial cells and adherence to polystyrene for the strains studied. Strains of serotype 3 were the less adherent bacteria to both epithelial cells and polystyrene, whereas two serotype $23 \mathrm{~F}$ strains were the most adherent ones. Xylitol at
0.5 and $5 \%$ diminished, although not significantly, bacterial adherence in six and four strains, respectively.

\section{DISCUSSION}

The adherence of $S$. pneumoniae to epithelial cells has been widely studied. However, studies on the adherence ability of this organism to abiotic materials are scarce $(3,4,17,18)$, but the pneumococcal adherence properties may be of interest in clinical situations where inert material is implanted (tympanostomy tubes, cochlear implants, ventriculostomy derivations, and so on) (5). Furthermore, bacterial adherence is considered to be the first step in biofilm development (19). We have observed notable differences in the adherence ability of pneumococcal strains. Two serotype $23 \mathrm{~F}$ strains and one serotype $6 \mathrm{~B}$ strain were the most adherent strains. However, all serotype 3 strains showed the lowest adherence ability, which confirms previously published results $(3,4)$.

Pneumococcal adherence to epithelial cells involves the recognition of host cell receptor glycoconjugates by pneumococcal surface structures (20), but the bacterial adhesins have not been well characterized so far, except for PsaA (16). A pneumococcal adherence and virulence factor A (PavA), displayed to the cell outer surface of pneumococcus, could modulate expression or function of important virulence determinants (21). It has been reported the low ability of serotype 3 strains to bind epithelial cells, which could be related to their great amount of capsular polysaccharide $(22,23)$, and possibly to the opaque phenotype, characteristic of the majority of capsulated strains $(24,25)$. The low adherence observed in the three serotype 3 strains tested here also confirms such observations. However, nonencapsulated strains or isogenic nonencapsulated derivatives of capsulated pneumococci that were usually of transparent phenotype showed greater binding ability to epithelial cells than that of the capsulated WT strains (26). Pneumococcal adherence to epithelial cells not only depends on the bacteria but also on the host cells. It seems that some host receptors are implicated in such binding and that certain host genes are specifically involved (26). In addition, host cell modifications induced by external agents, such as coinfections with respiratory syncitial virus, can enhance pneumococcal adhesion (27). Our results show an interesting relationship between pneumococcal adherence to epithelial cells and polystyrene material, suggesting that some mechanisms for bacterial adhesion could be common for binding both biotic and abiotic material.

We previously reported the ability of gerbil sera to diminish pneumococcal adhesion to polystyrene plates (4), and other authors have described the inhibitory effect of C-reactive protein (28), sialylated oligosaccharides alone or covalently coupled to HSA (29), $N$-acetylcysteine, and hydrocortisone (30) on adhesion of pneumococcal strains to host cells. The results of this study show that albumin in solubilized form or on pretreated polystyrene plates diminishes pneumococcal adherence in $>80 \%$ among the most adherent strains. However, for the least adherent strains (all 
serotype 3 strains), the adherence on pretreated plates increased slightly.

The effects of serum and albumin on bacterial adhesion have been widely investigated, and most studies show that exposure to both compounds persistently diminish adherence of many organisms to a variety of abiotic materials $(1,4)$, but to the best of our knowledge, no information regarding the effect of albumin on pneumococcus has been published. Our results might be of interest for preventing pneumococcal adhesion to some inert materials, such as tympanostomy tubes, cochlear implants, and ventriculostomy derivations, devices that may be associated with serious pneumococcal infections. The antiadhesive effect of albumin may be because of its acidic structure that raises the surface net negative charge increasing the repulsion between electric double layers adjacent to the organism and the polystyrene plate $(1,4)$.

The role of xylitol in preventing acute otitis media in children has been investigated. In two clinical trials, regular consumption of xylitol after each meal five times a day was effective in preventing acute otitis media by $30-40 \%(9,10)$, but such beneficial effect has not been shown in children who received xylitol only when they had an acute respiratory infection (31), during the respiratory infection season (32), or if they had tympanostomy tubes (10). Nevertheless, the possible beneficial effect of xylitol for preventing otitis media in children could be due to a direct antimicrobial effect $(11,12)$, interference with bacterial adherence (12), effect on the oxidative burst and bacterial killing in polymorphonuclear leukocytes (14), or alterations in capsule gene expression of pneumococci (33). Our results demonstrate a direct antimicrobial effect of xylitol on the pneumococcal strains tested with MIC values of 5-15\%, but bacterial growth of one strain was diminished even with concentrations of $0.5 \%$, which can be easily achieved in saliva, although transitorily, in children who received xylitol chewing gum (34). We found an inhibitory effect of xylitol on the adherence of some pneumococci to both abiotic material and epithelial cells, although such antiadhesive effect was not statistically significant using strict statistical analysis. Nevertheless, a previous published work showed the inhibitory effect of xylitol on pneumococcal adherence (12). Therefore, the possible beneficial effect of xylitol in preventing otitis media in children could be multifactorial highlighting its antimicrobial effect, which was showed in in vitro studies.

A remarkable limitation to this study is the relative low number of isolates that were tested. Hence, it will be necessary to confirm the adhesion findings by testing a larger number of clinical isolates.

In summary, pneumococcal adherence to polystyrene plates and epithelial cells was variable among strains, but there was a good correlation between ability of the different strains for binding both surfaces, being serotype 3 strains the less adherent organisms. Because albumin, but not xylitol, diminished pneumococcal adherence in different experimental conditions, this study supports the case for the use of albumin as coatings for medical devices to inhibit pneumococcal adherence on abiotic materials. However, we suggest that the possible beneficial effect of xylitol for preventing some pneumococcal infections may be because of its antimicrobial activity rather than to its effect on adherence.

Acknowledgment. We thank Dr. Juanjo Granizo (Grana Data S.L., Pozuelo De Alarcón, Madrid, Spain) for his statistical advice.

\section{REFERENCES}

1. An YH, Blair KB, Martin KL, Friedman RJ 2000 Macromolecule surface coating for preventing bacterial adhesion. In: An YH, Friedman RJ (eds) Handbook of Bacterial Adhesion: Principles, Methods, and Applications. Humana Press Inc, Totowa, NJ, pp $609-625$

2. Braxton EE Jr, Ehrlich GD, Hall-Stoodley L, Stoodley P, Veeh R, Fux C, Hu FZ, Quigley M, Post JC 2005 Role of biofilms in neurosurgical device-related infections. Neurosurg Rev 28:249-255

3. Allegrucci M, Sauer K 2007 Characterization of colony morphology variants isolated from Streptococcus pneumoniae biofilms. J Bacteriol 189:2030-2038

4. Huelves L, del Prado G, Rodriguez-Cerrato V, Gracia M, Cenjor C, Granizo JJ, Ponte C, Soriano F 2007 Adherence of Streptococcus pneumoniae to polystyrene plates, effect of serum on adhesion, and virulence in the gerbil otitis media model. Microb Pathog 43:114-119

5. Ruohola A, Heikkinen T, Meurman O, Puhakka T, Lindblad N, Ruuskanen O 2003 Antibiotic treatment of acute otorrhea through tympanostomy tube: randomized double-blind placebo-controlled study with daily follow-up. Pediatrics 111:10611067

6. Wei BP, Robins-Browne RM, Shepherd RK, Clark GM, O'Leary SJ 2008 Can we prevent cochlear implant recipients from developing pneumococcal meningitis? Clin Infect Dis 46:e1-e7

7. Dickinson RB, Nagel JA, Proctor RA, Cooper SL 1997 Quantitative comparison of shear-dependent Staphylococcus aureus adhesion to three polyurethane ionomer analogs with distinct surface properties. J Biomed Mater Res 36:152-162

8. Kinnari TJ, Peltonen LI, Kuusela P, Kivilahti J, Könönen M, Jero J 2005 Bacterial adherence to titanium surface coated with human serum albumin. Otol Neurotol 26:380-384

9. Uhari M, Kontiokari T, Koskela M, Niemela M 1996 Xylitol chewing gum in prevention of acute otitis media: double blind randomized trial. BMJ 313:11801184

10. Uhari M, Tapiainen T, Kontiokari T 2000 Xylitol in preventing acute otitis media. Vaccine 19:S144-S147

11. Kontiokari T, Uhari M, Koskela M 1995 Effect of xylitol on growth of nasopharyngeal bacteria in vitro. Antimicrob Agents Chemother 39:1820-1823

12. Kontiokari T, Uhari M, Koskela M 1998 Antiadhesive effects of xylitol on otopathogenic bacteria. J Antimicrob Chemother 41:563-565

13. Tapiainen T, Sormunen R, Kaijalainen T, Kontiokari T, Ikaheimo I, Uhari M 2004 Ultrastructure of Streptococcus pneumoniae after exposure to xylitol. J Antimicrob Chemother 54:225-228

14. Renko M, Valkonen P, Tapiainen T, Kontiokari T, Mattila P, Knuuttila M, Svanberg M, Leinonen M, Karttumen R, Uhari M 2008 Xylitol-supplemented nutrition enhances bacterial killing and prolongs survival of rats in experimental pneumococcal sepsis. BMC Microbiol 8:45

15. Clinical and Laboratory Standards Institute 2006 Performance Standards for Antimicrobial Susceptibility Testing, 16th Informational Supplement: Document M100S16. CLSI Press, Wayne, PA

16. Berry AM, Paton JC 1996 Sequence heterogeneity of PsaA, a 37-kilodalton putative adhesin essential for virulence of Streptococcus pneumoniae. Infect Immun 64:5255-5262

17. Moscoso M, García E, López R 2006 Biofilm formation by Streptococcus pneumoniae: role of choline, extracellular DNA, and capsular polysaccharide in microbial accretion. J Bacteriol 188:7785-7795

18. Domenech M, García E, Moscoso M 2009 Versatility of the capsular genes during biofilm formation by Streptococcus pneumoniae. Environ Microbiol 11:2542-2555

19. McLandsborough L, Rodríguez A, Pérez-Conesa D, Weiss J 2006 Biofilms: at the interface between biophysics and microbiology. Food Biophys 1:94-114

20. Cundell DR, Gerard NP, Gerard C, Idanpaan-Heikkila I, Tuomanen EI 1995 Streptococcus pneumoniae anchor to activated human cells by the receptor for platelet-activating factor. Nature 377:435-438

21. Pracht D, Elm C, Gerber J, Bergmann S, Rohde M, Seiler M, Kim KS, Jenkinson HF, Nau R, Hammerschmidt S 2005 PavA of Streptococcus pneumoniae modulates adherence, invasion and meningeal inflammation. Infect Immun 73:2680-2689

22. Adamou JE, Wizemann TM, Barren P, Langermann S 1998 Adherence of Streptococcus pneumoniae to human bronchial epithelial cells (BEAS-2B). Infect Immun $66: 820-822$

23. Talbot UM, Paton AW, Paton JC 1996 Uptake of Streptococcus pneumoniae by respiratory epithelial cells. Infect Immun 64:3772-3777

24. Kim JO, Weiser JN 1998 Association of intrastrain phase variation in quantity of capsular polysaccharide and teichoic acid with the virulence of Streptococcus pneumoniae. J Infect Dis 177:368-377

25. Kim JO, Romero-Steiner S, Sorensen UB, Blom J, Carvalho M, Barnard S, Carlone G, Weiser JN 1999 Relationship between cell surface carbohydrates and intrastrain 
variation on opsonophagocytosis of Streptococcus pneumoniae. Infect Immun 67:2327-2333

26. Bootsma HJ, Egmont-Petersen M, Hermans PW 2007 Analysis of the in vitro transcriptional response of human pharyngeal epithelial cells to adherent Streptococcus pneumoniae: evidence for a distinct response to encapsulated strains. Infect Immun 75:5489-5499

27. Hament JM, Aerts PC, Fleer A, Van Dijk H, Harmsen T, Kimpen JL, Wolfs TF 2004 Enhanced adherence of Streptococcus pneumoniae to human epithelial cells infected with respiratory syncytial virus. Pediatr Res 55:972-978

28. Gould JM, Weiser JN 2002 The inhibitory effect of C-reactive protein on bacterial phosphorylcholine platelet-activating factor receptor-mediated adherence is blocked by surfactant. J Infect Dis 186:361-371

29. Barthelson R, Mobasseri A, Zopf D, Simon P 1998 Adherence of Streptococcus pneumoniae to respiratory epithelial cells is inhibited by sialylated oligosaccharides. Infect Immun 66:1439-1444
30. Riise GC, Qvarfordt I, Larsson S, Eliasson V, Andersson BA 2000 Inhibitory effect of $\mathrm{N}$-acetylcysteine on adherence of Streptococcus pneumoniae and Haemophilus influenzae to human oropharyngeal epithelial cells in vitro. Respiration 67:552-558

31. Tapiainen T, Luotonen L, Kontiokari T, Renko M, Uhari M 2002 Xylitol administered only during respiratory infections failed to prevent acute otitis media. Pediatrics 109:E19

32. Hautalahti O, Renko M, Tapiainen T, Kontiokari T, Pokka T, Uhari M 2007 Failure of xylitol given three times a day for preventing acute otitis media. Pediatr Infect Dis J 26:423-427

33. Kurola P, Tapiainen T, Kaijalainen T, Uhari M, Saukkoriipi A 2009 Xylitol and capsular gene expression in Streptococcus pneumoniae. J Med Microbiol 58:1470_ 1473

34. Tapiainen T, Renko M, Kontiokari T, Uhari M 2002 Xylitol concentrations in the saliva of children after chewing xylitol gum or consuming a xylitol mixture. Eur J Clin Microbiol Infect Dis 21:53-55 